UCRL-ID-120749

\title{
Plutonium-Bearing Materials Feed Report for the DOE Fissile Materials Disposition Program Alternatives
}

\author{
W. G. Brough \\ S. T. Boerigter
}

April 6, 1995

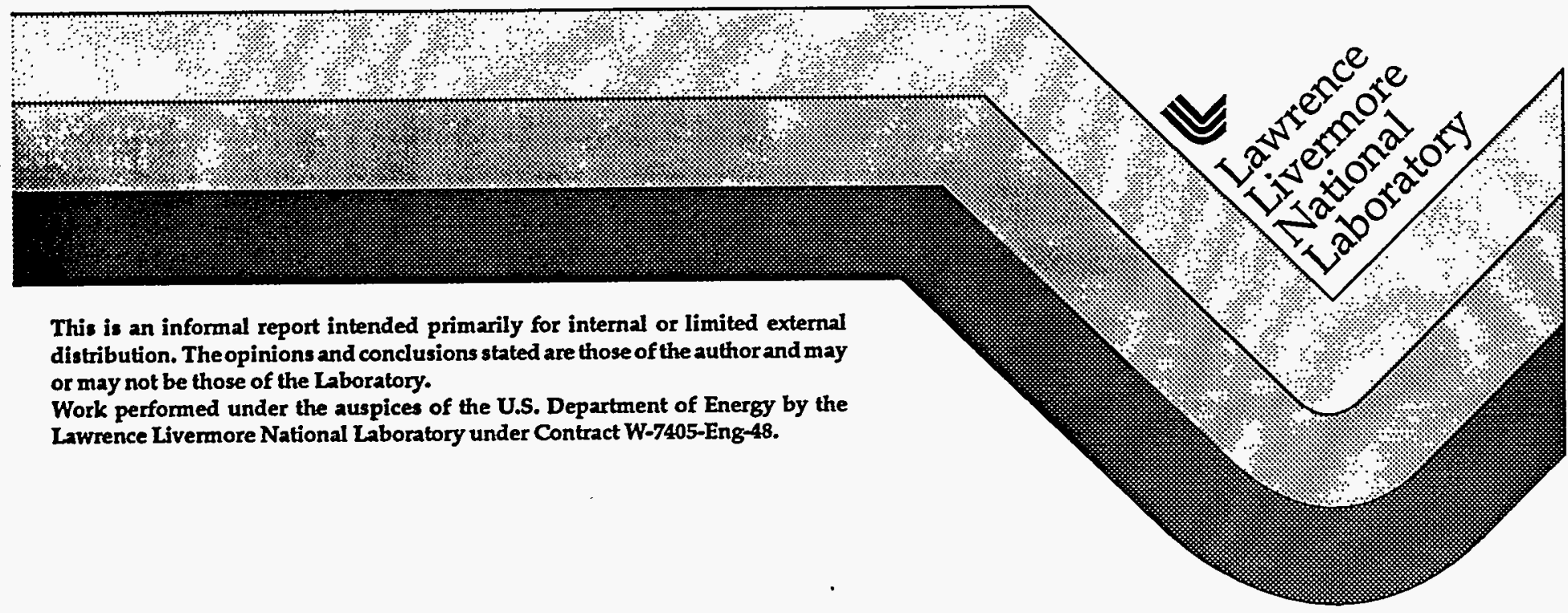




\section{DISCLAIMER}

This document was prepared as an account of work sponsored by an agency of the United States Government. Neither the United States Government nor the University of California nor any of their employees, makes any warranty, express or implied, or assumes any legal liability or responsibility for the accuracy, completeness, or usefulness of any information, apparatus, product, or process disclosed, or represents that its use would not infringe privately owned rights. Reference herein to any specific commercial product, process, or service by trade name, trademark, manufacturer, or otherwise, does not necessarily constitute or imply its endorsement, recommendation, or favoring by the United States Government or the University of California. The views and opinions of authors expressed herein do not necessarily state or reflect those of the United States Government or the University of California, and shall not be used for advertising or product endorsement purposes.

This report has been reproduced directly from the best available copy.

Available to DOE and DOE contractors from the Office of Scientific and Technical Information

P.O. Box 62, Oak Ridge, TN 37831

Prices available from (615) 576-8401, FTS 626-8401

Available to the public from the

National Technical Information Service

U.S. Department of Commerce

5285 Port Royal Rd.

Springfield, VA 22161 


\section{DISCLAIMER}

Portions of this document may be illegible in electronic image products. Images are produced from the best available original document. 


\title{
Plutonium-Bearing Materials Feed Report for the \\ DOE Fissile Materials Disposition Program Alternatives
}

\author{
April 6, 1995
}

\author{
Winslow G. Brough \\ Lawrence Livermore National Laboratory \\ NAI/Systems Modeling and Analysis
}

\author{
Stephen T. Boerigter \\ Los Alamos National Laboratory \\ TSA-7/Technology Modeling and Analysis
}




\section{Purpose}

The purpose of this feed report is to provide a list of plutonium-bearing feed materials, by location and type, currently considered excess to Defense Programs. DOE/MD will use this complete listing of possible feed materials for its determination of the feed materials which fall within the scope of the Materials Disposition Program for purposes of the programmatic environmental impact statement (PEIS) and record of decision (ROD) activities currently underway. This report will be updated should significant changes in stockpile predictions or other conditions warrant.

\section{Objectives}

- To provide a database for MD to use in establishing a reference feed inventory for consideration by disposition alternatives.

- To adequately categorize the present plutonium inventory with respect to possible feeds for potential processing scenarios which may be utilized by the various DOE programs.

- To provide material input stream characterization information which will become the basis for bounding cases with regard to environmental impacts and costs of the plutonium disposition alternatives.

- To facilitate a systematic assessment of each disposition alternative.

- To provide the materials inventory basis for evaluating potential additional benefits that could be realized by the ability of some disposition alternatives to help accomplish the missions of other organizations.

\section{Scope}

All plutonium-bearing materials reported to the DOE Nuclear Materials Management and Safeguards System (NMMSS) and which are excess to Defense Program needs are included in this report. Plutonium-bearing materials that have already been discarded as low-level waste, transuranic (TRU) waste, or high-level waste are no longer tracked by the NMMSS and are excluded from this report.

\section{References}

NMMSS P-112 Report, September, 1994.

NMMSS I-17 Report, DOE Inventory Profile (U).

American National Standard for Nuclear Materials, Unirradiated Pu Scrap -- Classification, ANSI N15.10-1987.

DOE Production \& Planning Directive, 1995-0.

Material from Presentations by Leonard Myers (DP-22), December, 1994 at SANL-Livermore. Communications from Peter Dessaules (DP-22), Dec. 1994 - Jan. 1995.

Pretreatment Processes for Immobilization -- Initial Report, LLNL, L-18802-11, Feb. 27, 1995.

\section{Background}

As presently configured, the DOE Fissile Materials Disposition Program is focused on developing a program for the selection and implementation of technologies and facilities that can realize the long-term disposition of surplus fissile materials created over the past 50 years by the nuclear weapons programs. The materials returning from the nuclear stockpile, together with the other existing inventories of weapons-useable fissile materials, have generated a concern for international 
security and environmental impacts resulting from what will be the near-term and long-term disposition of these materials. The DOE Materials Disposition program (MD) has defined the scope of the disposition PEIS as encompassing those excess materials that exist in a weapons-useable form or which may easily be converted to a weapons usable form. An initial program effort requires the identification of the potential inventory of material that may be available for disposition by the MD program. With that information, disposition alternatives can then be evaluated.

Substantial processing of plutonium has occurred over the course of the nation's weapons and nuclear energy programs which have resulted in significant inventories of plutonium in various chemical and physical forms in addition to weapons components. To assist in information development for determining materials disposition impacts, this report defines material categories based upon potential processing requirements. Since this was not the basis for material identification in the NMMSS system, some effort was required to map the present inventory into categories that are more suitable for these analyses. The conventions "Rich Scrap" and "Lean Scrap" which are listed on the table have generally been described as residues on the DOE inventory records. Table $\mathrm{C}^{1}$ shows the present inventory of materials by these defined categories at selected individual sites and, collectively, for the remaining sites. Current DOE programmatic efforts are focusing corrective actions on stabilizing existing stored materials listed in Table C1 in response to Defense Nuclear Facility Safety Board (DNFSB) recommendation 94-1 and recent vulnerability analyses, and these actions are indicated in Figure 1. It is assumed that these corrective actions will be completed prior to the start of disposition activities and that the source of plutonium for disposition will be the material stored in stabilized forms defined by $94-1$ from the existing programs.

Table $\mathrm{C} 2$ provides additional insight to Table $\mathrm{C} 1$ by separating material as either 'weapon grade' or 'other grades'. Tables C3 and C4 provide breakdowns by subcategories of some of the main categories shown in Table C1.

Irradiated fuel is currently excluded from consideration in the PEIS since it in principle meets the NAS defined "spent fuel standard". However, if other DOE program stabilization or discard actions should result in recovery of the plutonium inventory from the irradiated fuel, then such recovered plutonium would likely require further disposition activities. This possibility is shown by the dashed arrows in Figure 1.

Since DOE corrective actions have not yet been planned or executed, it is not possible to specify the exact form, quantity, or location of the Pu contained in the stabilized scrap or irradiated materials which may be available for disposition, again depicted by the dashed line in Figure 1 . In order for planning to proceed in $\mathrm{MD}$, bounding estimates should be made of the potential quantities of plutonium which may become available in each category based on the current data base. If plutonium is recovered from DOE spent fuel as part of the 94-1 remediation activities conducted by other DOE programs, then the plutonium recovered from the spent fuel would be the total inventory currently in spent fuel and would likely be in the form of an impure oxide. Further, it is assumed that all $\mathrm{Pu}$ in the lean scrap categories would be discarded as waste as part of 94-1 remediation by the responsible DOE programs, but that processing or stabilization of the rich scrap categories by other DOE programs could result in some concentrated plutonium in the form of impure oxides or impure metals which would become available for further disposition activities. The bounding limit for such material would be the total $\mathrm{Pu}$ inventory currently projected to be in the rich scrap category. Note that the bulk residues that comprise the rich scrap category defined in this report are in a gray area and subject to future guidance from MD.

Nuclear weapons declared excess to the Department of Defense and DOE Defense Program needs are also considered to be available for disposition. Table C3 summarizes the excess plutonium,

${ }^{1}$ Actual numbers for Tables $\mathrm{C} 1-\mathrm{C} 4$ are in the classified appendix to this report. 
available as pits from this source. Two values are noted: 1) excess plutonium from weapons as declared by the Nuclear Weapons Council and 2) excess plutonium projected for the year 2005.

\section{Identification of Candidate Inventory for Materials Disposition}

To assure ourselves that all excess plutonium-bearing materials are being properly considered, we have reviewed the entire national inventory currently in our study as contained in the DOE Nuclear Materials Management and Safeguards System (NMMSS) data base.- That material which was not considered to be excess to Defense Programs needs was then removed, and only the excess material was reported in this study.

Much of the plutonium-bearing inventory is sufficiently characterized in the NMMSS data base for conceptual development of disposition alternatives. There remains, however a significant fraction of plutonium-bearing materials that are not sufficiently characterized in the NMMSS database to identify appropriate processing requirements for the purposes of evaluating additional benefits of certain disposition alternatives. Careful evaluation of the NMMSS material categorization codes has shown, however, that a deconvolution of the NMMSS codes can be performed to provide much of the additional detail. Note that no other DOE-wide database exists that can provide all the needed information. Individual site databases retain, although non-uniformly, much of the additional information required. For instance, the Rocky Flats residue categories, which contain chemical form and total mass information, were available and were analyzed to help better understand the scrap and residue issues. Further effort will be required to collect and catalog individual site data as this task continues.

The first requirement is to identify how much of the existing national inventory may become available for disposition. Figure 2 pictorially describes the national plutonium inventory. To the left are the plutonium-bearing wastes that have been declared TRU waste. These materials are no longer included in the NMMSS database. To the right is the plutonium inventory required for national security purposes. In the center are materials that are neither required for national security, nor have been declared as waste. Note that these materials may have some progammatic use other than Defense Programs. These materials are accountable within the framework of the NMMSS database and are therefore potentially excess material. It is important to recognize that the leaner materials to the left side of this scale are more difficult to process and store than the richer materials to the right side. Of the potentially excess material, some may be required for DOE programmatic reserves and activities as noted above and would not be available for disposition. From the stockpile plans and the production and planning directives, it is well understood how much inventory is needed for security purposes.

At the other end of the potentially excess material spectrum is the quantity of plutonium-bearing material that represents the leaner inventories, but that are still accountable in the NMMSS system. Detailed plans for the management of these low plutonium content materials are under development by DOE/EM and the sites as discussed earlier. These are being managed by DOE/EM because the disposition is dominated by waste management issues rather than non-proliferation issues. It is likely that many of these materials may be packaged for disposal at the Waste Isolation Pilot Plant (WIPP), while other materials are not so easily discarded. An attempt to identify candidate materials which will likely be discarded and those that may require further treatment is made below.

An analysis of possible scrap categorizations between rich scrap and lean scrap (to be defined below) has been made based on the Rocky Flats Plant residue data base which lists the characteristics of the material, $\mathrm{Pu}$ content, and total mass by IDC code. Data from other sites was not available in the same detail, so our current projections were based on the Rocky Flats data 
which comprises the bulk of the residue materials at present. Calculations were made which evaluated the waste management impact by estimating the total number of drums of waste which would be required to either 1) satisfy WIPP waste acceptance criteria with respect to fissile material loading limits or 2) the mass loading limits per drum, whichever was greater. Processing "cut-off" limits, based on the \% Pu content in each IDC category, were used in a decision as to whether to assume possible processing to concentrate the scrap, or to-simply discard the scrap in WIPP without further processing. Figure 3 shows the logarithmic plots of various trade-off parameters as a function of this "cut-off" value. As can be seen in Figure 3, the number of waste drums rise rapidly above the $2 \%$ "cut-off" limit. This corresponds to the drop in the quantity of Pu which is being processed, indicating that the waste drum counts are being driven by the inclusion of the $\mathrm{Pu}$ in the waste form. Note that estimated costs for just the WIPP recharge (based on at least $\$ 10,000$ per drum as assumed for the DOE Reconfiguration Program) for the number of drums which would be required to discard the RFP residues directly without processing would be an appreciable fraction of one billion dollars and that an appreciable fraction of the current WIPP volume would be consumed. Selection of a "cut-off" value higher than $2 \%$ would cause rapidly rising costs for waste management operations. Conversely, selection of values for the "cut-off" below $2 \%$ would reduce waste management costs, but at a slower rate and would certainly drive up processing costs due to the increased quantity and variety of materials which would be processed. For this reason, the "cut-off" of $2 \%$ was used in arriving at the estimated splits between lean scrap and rich scrap as described below.

An additional factor was applied to the decision as to whether or not to process the various scrap categories. Many materials, such as the Leco crucibles, represent very difficult processing problems as compared to the pyrochemical salts. Hence, only those categories which were judged to be relatively easy to process using current common technology were included in the rich scrap category in addition to the $2 \%$ constraint.

\section{Development of the Disposition Feed Materials Inventory}

The basis of the Fissile Materials Disposition's Feed Materials Inventory is the existing plutonium inventory database maintained by the DOE's Nuclear Materials Management and Safeguards System (NMMSS). The NMMSS database contains information that identifies plutonium-bearing materials. Of specific interest to disposition planning activities are the NMMSS data that identify (1) material location, (2) the plutonium isotopic ranges, (3) the plutonium weight as an element, (4) the "composition of ending inventory" (COED codes (a NMMSS categorization definition) that identify the process that derived the material, its usage, chemical form, physical form, and (5) the American National Standards Institute (ANSI) codes for those materials that have been identified as scrap.

These COEI codes and/or the 'scrap' codes serve well to identify the inventory of plutonium with respect to production operations but do not sufficiently classify the plutonium-bearing materials for ascertaining chemical processing requirements for disposition. This additional information, to a certain extent, is maintained by the individual sites where some recovery operations are performed but is not reported to the NMMSS inventory database.

Figure 4 shows the relationship between plutonium inventory information sources. The NMMSS data base is the result of assigning the site data bases to specific NMMSS COEI and ANSI scrap categories, and primary chemical and mass data are not included. Once disposition activities are underway, detailed inventory data that accurately represents the physical entities will have to be used to make specific processing/handling decisions. In some cases, however, such accurate and precise information is not required. The approach to creating the information in this report is an 
optimization between the information requirements for support of the PEIS and ROD activities (selection of disposition alternatives) and the cost of obtaining data with a specific fidelity.

Given the inherent difficulty in correlating and assessing information from the site databases, and the desire to maintain consistency with the DOE-wide plutonium inventory database, the NMMSS database is used as the basis for this study. Future work needs to be authorized and funded to systematically evaluate the feed category inventories created in this report by analyzing specific portions of the site databases. This analysis would be coupled to the feed material requirements for implementation of specific disposition alternatives.

\section{Plutonium-Bearing Surplus Fissile Materials Feed Categories}

It is necessary to identify and adequately characterize the materials so that disposition methods can be selected for managing the inventory. To this end, material disposition categories have been defined, and the materials reported in the NMMSS database are being mapped into the disposition feed list. The selection of the categories was derived after review of site-specific categorization schemes, and COEI and ANSI codes.

All of the COEI and ANSI codes will be mapped into the categories listed below. When composition and scrap codes do not provide sufficient information for proper classification, other information such as project codes or information from the sites will be required to categorize all of the materials. In time, the feed list will be correlated with site-specific categories.

Plutonium-bearing materials are being cataloged according to the chemical processes which may be required for potential elimination (disposition or discard) of the plutonium. The eleven primary material categories are listed below with a description of each category. Most categories will have sub categories that identify more specifically the physical or chemical form which may affect the chemical processes required for disposition of the plutonium.

Three basic rules were followed in developing the categorization scheme:

Lowest common denominator categories. All plutonium-bearing materials are categorized such that, for any given disposition alternative, the material from a given category (or sub category) would not likely be split into separate disposition process lines. It is most likely, however, that several categories or sub categories can be combined to feed a single process line for a given alternative.

Mutual exclusion. All categories and sub categories should be mutually exclusive with any other category or sub category; i.e., any existing quantity of plutonium-bearing material should not be able to qualify for more than one category or sub category.

Process characterized. Each category and sub category should be sufficiently characterized to be able to identify required processing operations of the material for any given disposition option. 


\section{A) Primary Plutonium-Bearing Surplus Fissile Material Feed Categories}

(Note: Material that has already been dispositioned as low-level or TRU waste is excluded from all disposition categories).

I. Pits

Plutonium weapon component or assembly having a serial or.other identification number.

II. Clean Metal

Essentially pure plutonium metal that meets weapons specifications, generally $<100 \mathrm{ppm}$ of any given impurity. The plutonium can be weapons grade, fuels grade, or reactor grade. The metal may have oxidation or casting residues on the surface. The only major impurities are gallium and decay products (e.g., Am, Np, U).

III. Impure Metal/Alloys

Plutonium bearing metal/alloy that does not meet weapon specifications for chemical purity. Impurities constitute $<50 \%$ of the net weight. Sub categories differentiate alloys, impurities, and concentrations.

IV. Clean Oxide

Oxidized plutonium $\left(\mathrm{PuO}_{2}\right)$ containing less than $3 \%$ impurities.

V. Impure Oxide

Oxidized plutonium $\left(\mathrm{PuO}_{2}\right)$ containing 3 - 50\% impurities that may require chemical processing for some disposition options. Sub categories differentiate impurities and concentrations.

VI. Compounds (other than oxides)

Plutonium fluorides, carbides, chlorides, etc., containing $\leq 50 \%$ impurities that may require chemical processing for some disposition options. Sub categories differentiate compounds, impurities and concentration levels.

VII. Rich Scrap

This category includes materials which contain relatively leaner concentrations of plutonium than the preceding categories. It includes plutonium-bearing materials (metals/alloys/oxides/compounds, etc.) that principally contain non-plutonium elements and/or compounds (e.g., $\mathrm{Al}_{2} \mathrm{O}_{3}, \mathrm{C}$ ) in the range of $>50 \%$ to $\leq 98 \%$ impurities. Sub categories differentiate impurities and concentration levels.

VIII. Lean Scrap

This category includes materials which contain very lean concentrations of plutonium such that they are likely to be declared waste at some future time. It generally includes plutonium-bearing materials (metals/alloys/oxides/compounds, etc.) that principally contain non-plutonium elements and/or compounds (e.g., $\mathrm{Al}_{2} \mathrm{O}_{3}, \mathrm{C}$ ) that are $>98 \%$ impurities. It 
also includes materials above $2 \% \mathrm{Pu}$ concentration but for which no known or no practical extraction technology exists to separate out the $\mathrm{Pu}$. However, it excludes materials which are easily concentrated to above $10 \% \mathrm{Pu}$ concentration.

IX. Reactor Fuel

Plutonium-bearing reactor fuel that has been manufactured, but not irradiated. Sub categories differentiate fuel assemblies (metals, oxides, carbides, alloys, etc.).

X. Irradiated Fuel

Plutonium-bearing material that meets the definition of 'spent nuclear fuel' in

40 CFR 191.02. This category contains a variety of fuel elements that are in several chemical forms (i.e., metals, oxides, carbides, alloys, etc.). This category is not currently included in the Materials Disposition baseline planning. However, remediation actions by other DOE programs may result in Pu becoming available for disposition.

(Note: 'High-level waste' as defined in 40 CFR 191.02, is excluded from this category and all other disposition categories).

XI. Miscellaneous

Plutonium-bearing materials that do not fit any of the above categories (e. g., the ZeroPower Plutonium Reactor (ZPPR) fuel elements at ANL-West). The majority of the material is presently in ZPPR fuel elements. In addition, there are experimental capsules, elements, and pins. Sub categories characterize these materials to identify specific requirements for disposition to any option. 


\section{B) Pu-Bearing Feed Material Sub-Categories}

\section{Pits (Main Category Type I) Sub Categories}

1. See Table C3.

2. See Table C3.

3. See Table C3.

4. See Table C3.

5. See Table C3.

\section{Clean Metal (Main Category Type II) Sub Categories}

\section{Buttons}

Unalloyed buttons product (unalloyed buttons produced in the reduction process or held by non-processors). Unalloyed buttons feed (unalloyed buttons used as feed in the casting or fuel tube fabrication process).

2. Billets, Ingots, Castings, and Rough Machinings

Unalloyed metal feed (unalloyed metal used as feed in the casting process). Unalloyed castings product (unalloyed castings produced in the casting process or held by nonprocessors). Unalloyed rough machined items product (all unalloyed material which has been rough machined, including machined ingots and billets for forming, in the rough machining process or held by non-processors). Unalloyed ingots feed (ingots of unalloyed material used as feed in the forming process). Unalloyed formed items product (all formed items of unalloyed material produced in the forming process, including fuel fabricated for heat source application, e.g., awaiting processing, encapsulation, or shipment. Also includes like material held by non-processors).

\section{Weapon Components}

Unalloyed finish machined items product (all finish machined products of unalloyed material, e.g., fuel elements, weapon parts, etc., produced in the finish machining process or held by non-processors). Unalloyed finish machined items feed (finish machined items of unalloyed material used as feed in the assembly process).

\section{Recovered Metal, and Miscellaneous Small Parts}

Unalloyed metal feed (unalloyed metal used as feed in the unirradiated recovery process). Unalloyed metal product (unalloyed metal produced in the unirradiated recovery process or held by non-processors). Unalloyed archive \&/or retained sample items (items of unalloyed material retained for historical or display purposes). Laboratory samples - unalloyed metal (samples of unalloyed material being held for analysis or being analyzed in the laboratory).

\section{Impure Metal/Alloys (Main Category Type II) Sub Categories}

\section{Alloys}

Alloyed buttons product (alloyed buttons produced in the reduction process or held by nonprocessors). Alloyed buttons feed (alloyed buttons used as feed in the casting or fuel tube fabrication process). Alloyed metal feed (alloyed metal used as feed in the casting process). Alloyed castings product (alloyed castings produced in the casting process or held by non- 
processors). Alloyed rough machined items product (all alloyed material which has been rough machined, including machined ingots and billets for forming, in the rough machining process or held by non-processors). Alloyed ingots feed (ingots of alloyed material used as feed in the forming process). Alloyed formed items product (all formed items of alloyed material produced in the forming process, including fuel fabricated for heat source application, e.g., awaiting processing, encapsulation, or shipment. Also includes like material held by non-processors). Alloyed finish machined items product (all finish machined products of alloyed material, e.g., fuel elements, weapon parts, etc., produced in the finish machining process or held by non-processors). Alloyed metal product (alloyed metal produced in the unirradiated recovery process or held by non-processors). Alloyed finish machined items feed (finish machined items of alloyed material used as feed in the assembly process). Alloyed metal (unirradiated) (metal which is canned and/or alloyed and constitutes $1 \%$ or more of the total weight).

\section{Impure Unalloyed Metal}

Unalloyed metal (unirradiated) (unalloyed metal that is scrap in the sense it is not useable in its present form, or has become contaminated with impurities to an extent not acceptable to the generating contractor).

\section{Clean Oxide (Main Category Type IV) Sub Categories}

no sub categories

\section{Impure Oxide (Main Category Type V) Sub Categories}

\section{Oxides}

Low-fired oxide or suboxides (temperature $<700$ degrees $C$ ). High-fired or sintered oxide (temperature $>700$ degrees $\mathrm{C}$ ).

\section{Pu-DU/NU Oxides}

Low-fired powders or pellets with depleted uranium oxide (temperature $<700$ degrees C). Sintered oxide with depleted uranium oxide (temperature $>700$ degrees $C$ ). Oxide containing both plutonium and uranium. Low-fired powders or pellets of plutonium oxidenormal uranium oxide (temperature $<700$ degrees $C$ ). Sintered plutonium oxide-normal uranium oxide for chemical processing (temperatures $>700$ degrees $C$ ).

\section{Pu-EU Oxides}

Low-fired powders or pellets with enriched oxide (temperature $<700$ degrees $C$ ). Sintered oxide with enriched uranium oxide (temperature $>700$ degrees $\mathrm{C}$ ). Noncombustibles containing both plutonium and enriched uranium.

\section{4. $\mathrm{Pu}-\mathrm{Np}$ Oxides}

Oxides containing both plutonium and neptunium. Uranium may be present. 


\section{Pu-Th Oxides}

Oxides containing both plutonium and thorium. Uranium may be present.

6. Pu-Be Oxides

Mixed oxides containing beryllium.

\section{Pu-Zr Oxides}

Mixed oxides containing zirconium.

\section{Compounds (Main Category Type VI) Sub Categories}

\section{Carbides}

Chemical combinations with carbon.

\section{Hydrides}

Chemical combinations with hydrogen.

\section{Nitrides}

Chemical combinations with nitrogen.

4. Halides

Plutonium halides - uranium halides.

\section{Encapsulated Compounds}

A general category for plutonium compounds encased in aluminum, stainless steel, tantalum, and the like.

6. Miscellaneous compounds.

All miscellaneous compounds not reported elsewhere.

\section{Rich Scrap (Main Category Type VII) Sub Categories - see earlier definition}

\section{Graphite}

This material consists of graphite crucible, molds, scarfings, fines, filters, and heels. Graphite materials which were generated from casting operations may be coated with 
calcium fluoride. Typically the plutonium concentration ranges from 2.0 to $8.3 \%$ for rich graphite scrap.

\section{Ash/ Ash and Soot Heels}

This material consists of ash produced from incinerating combustibles such as polyvinyl chloride, polyethylene/polypropylene, paper, liquid, nonleaded rubber gloves, filters with carbon, and wood. For Rocky Flats ash, components are silica (15 to 75\%, but typically 45 to $50 \%$ ), carbon ( 5 to $40 \%$, but typically $20 \%$ ) and minor components such as $\mathrm{Al}_{2} \mathrm{O}_{3}$, $\mathrm{CaO}, \mathrm{Fe}_{2} \mathrm{O}_{3}$, and $\mathrm{Na}_{2} \mathrm{O}$ can vary from 1 to $10 \%$. The plutonium concentration ranges from 2.0 to $7.4 \%$ for rich ash scrap. The ash heels consist of the undissolved solids that remain after ash and fly-ash dissolve in nitric acid. In general, ash heel (a fine particulate) contains the same constituents as the ash. However, the relative concentrations vary, depending on the solubility of the constituents. In general, soot heel contains high concentrations of carbon because of the abundance of carbon in fly-ash and carbon's relative insolubility in nitric acid.

\section{Heels}

This material consists of the undissolved solids that contain in excess of $2 \% \mathrm{Pu}$ and remain after nitric acid dissolution. Heels are categorized by the feed material to the dissolution operation, such as, grit; oil dry; sand, slag and crucible; filter residues, and nitrate salts.

\section{Plutonium Fluorides}

This material consists of plutonium fluorides that contain in excess of $2 \%$ Pu require processing. One type of contaminated fluoride at Rocky Flats is grease fluoride. Grease fluoride is plutonium fluoride that has come into contact with grease from the fluorination equipment.

\section{Sand, Slag, and Crucible (SS\&C)}

This material consists of SS\&C resulting from the calcium reduction of plutonium tetrafluoride. The crucible and sand consist of $\mathrm{MgO}$. Slag consists of chunks of calcium fluoride. Slag and crucible can be coarse pieces or pulverized materials. The crucible portion of the material, in particular, is contaminated with slag from the reduction process. The slag contaminant contains uncoalesced plutonium metal, some of the excess calcium metal, magnesium metal from the reaction of excess calcium with the $\mathrm{MgO}$ sand and crucible, and trace amounts of the pyrotechnic initiator or iodine used to start the reduction. For Rocky Flats SS\&C the plutonium concentration ranges from 2.0 to $44 \%$.

\section{Insulation - Filters}

This material consists of high-efficiency particulate air (HEPA) filters, asbestos, and heating mantles which contain in excess of $2 \%$ Pu. The HEPA filters are used on glovebox ventilation systems. These plutonium-contaminated filters consist of glass fibers and corrugated aluminum foil within a wooden or metal frame. Filters may also consist of polywound fluid filters.

\section{Ceramics (Chloride containing)}


This material consists of ceramic crucibles, stirrers, ER cups, and ceramic pieces that have been used with chloride salts $\left(\mathrm{CaCl}_{2}, \mathrm{NaCl}\right.$, and $\left.\mathrm{KCl}\right)$. Many of these result from pyrochemical processing operations such as electrorefining (ER), direct oxide reduction (DOR), and salt scrub. Attached to the crucible fragments is chloride salt scrap that contain plutonium in chloride, oxide, and metallic forms. The ceramics are made of magnesium oxide, zirconium oxide and alumina. For Rocky Flats the plutonium concentration in residue ceramics ranges from about 2.0 to $3.1 \%$.

\section{Sludge}

Sludges are in the form of a damp mass with the consistency of paste, or a mass that has been dried to some extent, and may contain fines. Actinide concentration is the only specific information currently available about the composition of sludges. Various types of sludges are: ferrite sludge, metal dissolving sludge, and filter sludge.

\section{Chloride Salts / Chloride Containing Oxides}

Pyrochemical operations involved molten chlorides (such as $\mathrm{NaCl}, \mathrm{MgCl}, \mathrm{CaCl}$, or $\mathrm{KCl}$ ), which were used to purify plutonium metal, reduce plutonium oxide, and remove plutonium from residue salts. The typical operations were Molten Salt Extraction (MSE), Direct Oxide Reduction (DOR), and Electrorefining (ER). A residue generated at Rocky Flats from scraping out tilt-pour furnaces is principally plutonium oxide containing significant quantities of chloride salts.

\section{Solutions}

This material consists of aqueous solutions that result from the extraction of plutonium from other materials in fuel elements. Most of the solutions are nitrates. Depending on what point the solutions are in the extraction process, they can contain additional materials such as fission products and uranium. Some of the solutions are caustic. Note that 94-1 remediation actions will likely eliminate this scrap category, with the Pu inventory going to dirty oxide.

\section{Non-Conforming Scrap}

Non-conforming scrap is that scrap that does not fit in any of the other scrap categories. This scrap is described individually for processing requirements.

\section{Lean Scrap (Main Category Type VIII) Sub Categories} Subcategories are not listed at this time

\section{Reactor Fuel (Main Category Type IX) Sub Categories}

1. Clad
a. Metal
b. Oxide 
c. Carbides

d. Alloys

2. Non-Clad
a. Metal
b. Oxide
c. Carbides
d. Alloys

\section{Irradiated Fuel (Main Category Type X) Sub Categories \\ 1. Low Burn-up}
a. Low-Concentration $\mathrm{Pu}$
b High-Concentration $\mathrm{Pu}$

2. High Burn-up
a. Low-Concentration $\mathrm{Pu}$
b High-Concentration $\mathrm{Pu}$

\section{Miscellaneous (Main Category Type XI) Sub Categories}

1. Plutonium-Aluminum Alloy

This material consists of plutonium metal alloyed with 1 weight percent aluminum. The plutonium isotopically is either weapons grade or reactor grade. The metal alloy is in the form of plates that are stainless steel clad.

\section{Plutonium-Uranium-Molybdenum Alloy}

This material consists of plutonium metal alloyed with uranium and 2 weight percent molybdenum. The plutonium isotopically is either weapons grade, fuels grade, or reactor grade. The plutonium composition ranges from 20 to 34 percent and the uranium concentration ranges from 62 to 68 percent. The metal alloy is in the form of plates that are stainless steel clad.

\section{Mixed Oxide}

This material consists of plutonium oxide mixed with uranium oxide and fabricated into fuel pins. The plutonium isotopically ranges from 12 to 26 percent plutonium 240 . The plutonium composition ranges from 13 to 27 weight percent. 


\section{Conclusions:}

This report has identified all plutonium which is currently excess to DOE Defense Programs under current planning assumptions. A number of material categories will clearly fall within the scope of the MD program, but the fate of the other categories are unknown at the present time. MD planning requires that estimates be made of those materials likely to be considered for disposition actions so that bounding cases for the PEIS can be determined and so that processing which may be required can be identified in considering the various alternatives. A systematic analysis of the various alternatives in reaching the preferred alternative requires an understanding of the possible range of values which may be taken by the various categories of feed materials. Table C1 identifies the current total inventories.excess to Defense Program planning needs and represents the bounding total of $\mathrm{Pu}$ which may become part of the $\mathrm{MD}$ disposition effort for all materials, except site return weapons.

The other categories, principally irradiated fuel, rich scrap, and lean scrap, have been discussed in the text. Future determinations will focus on the actual split between waste operations and disposition for non-Rocky Flats residues or scrap. As a bounding case, assume that all $\mathrm{Pu}$ in the rich scrap category as defined by the '2\% cut-off' and 'viability of processing' could be available for disposition. It is highly unlikely, however, that a significant fraction of the Pu currently listed in the lean scrap will be eliminated in any other way than waste operations.

Table $\mathrm{C} 5$ summarizes the ranges and expected quantities of $\mathrm{Pu}$ which could become the responsibility of the MD program. These values are to be used for assessing the impact of the various alternatives and for scaling operations to assess PEIS impact. Determination of the actual materials to be included in the disposition program will be done at a later date. This determination will involve a substantial additional effort to better identify and specify the actual materials by site. This additional effort would identify specific materials subject to disposition and will include $\mathrm{Pu}$ mass, total mass, form, matrix, and dominating impurities by specific element and concentration. 
Figure 1. Anticipated Flow of Current DOE Excess Plutonium Inventory

\section{Current DOE Fissile Material Inventory}

Pits

Clean Metal

Impure Metal/Alloys

Clean Oxide

Impure Oxide

Pu Compounds

Reactor Fuel

Miscellaneous

Rich Scrap

Irradiated Fuel

Lean Scrap

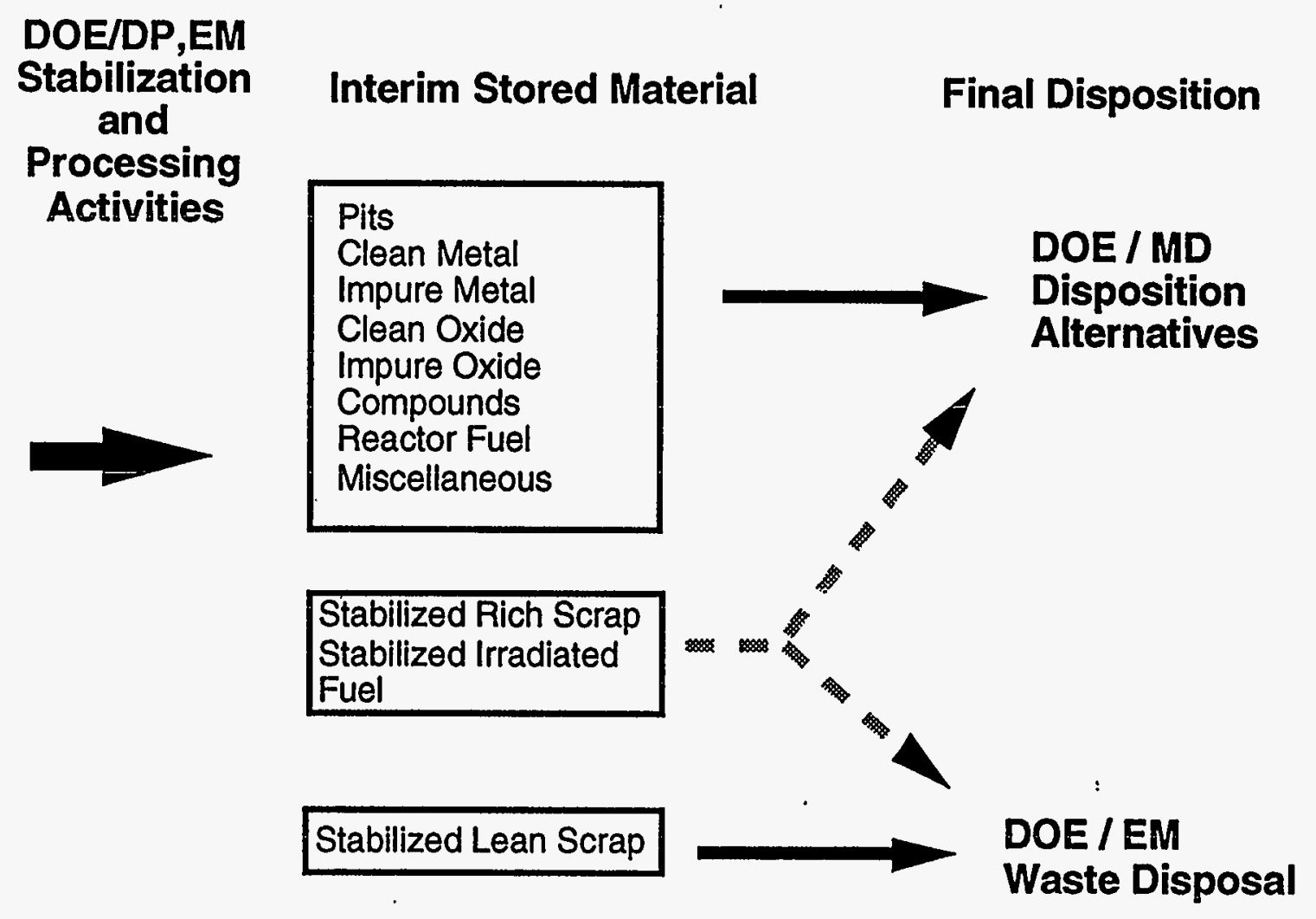


Figure 2. Plutonium Material Allocation and Disposition

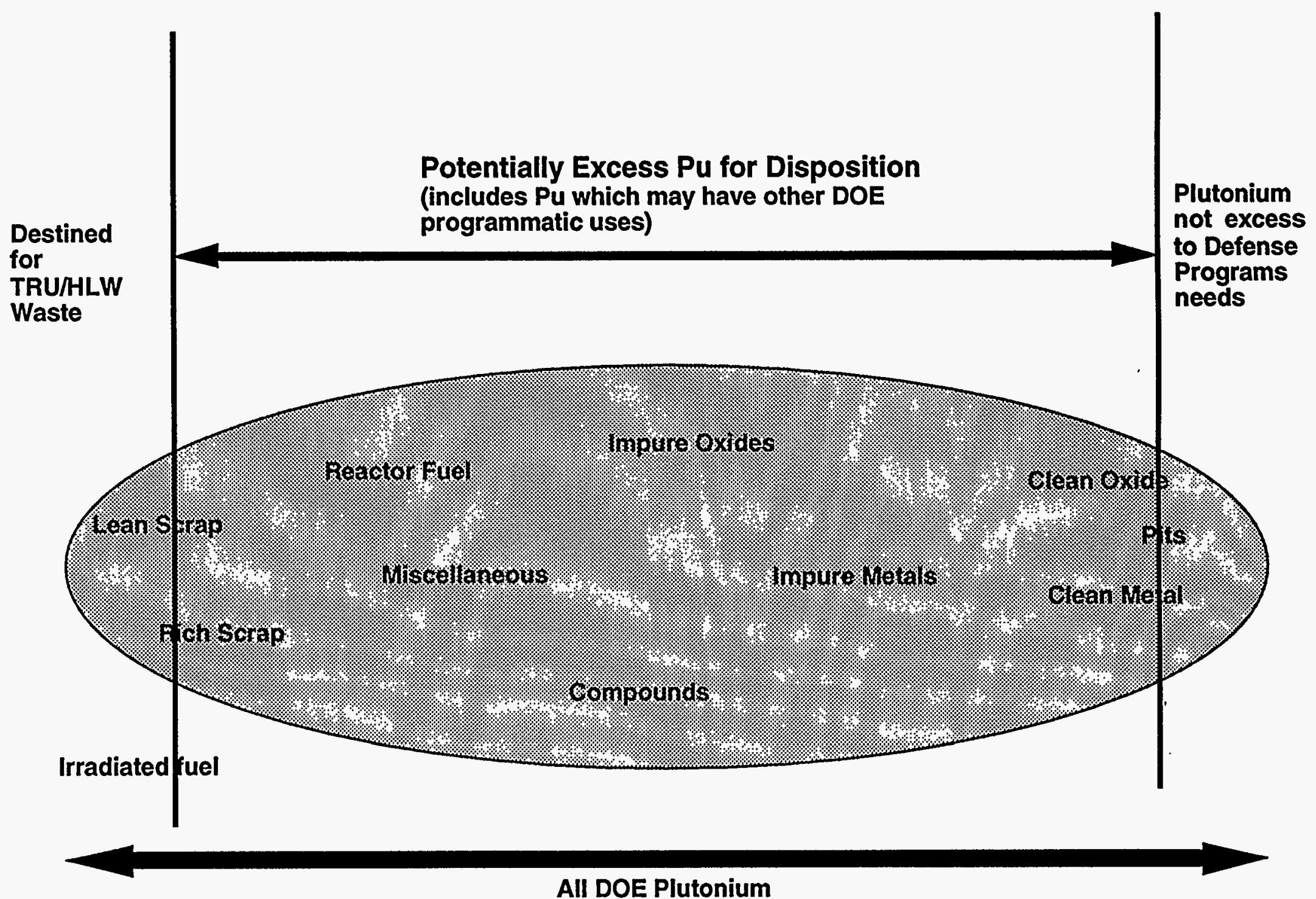


Figure 3: Tradeoffs versus "cut-off" $\mathrm{Pu}$ Concentration for IDC Category Processing

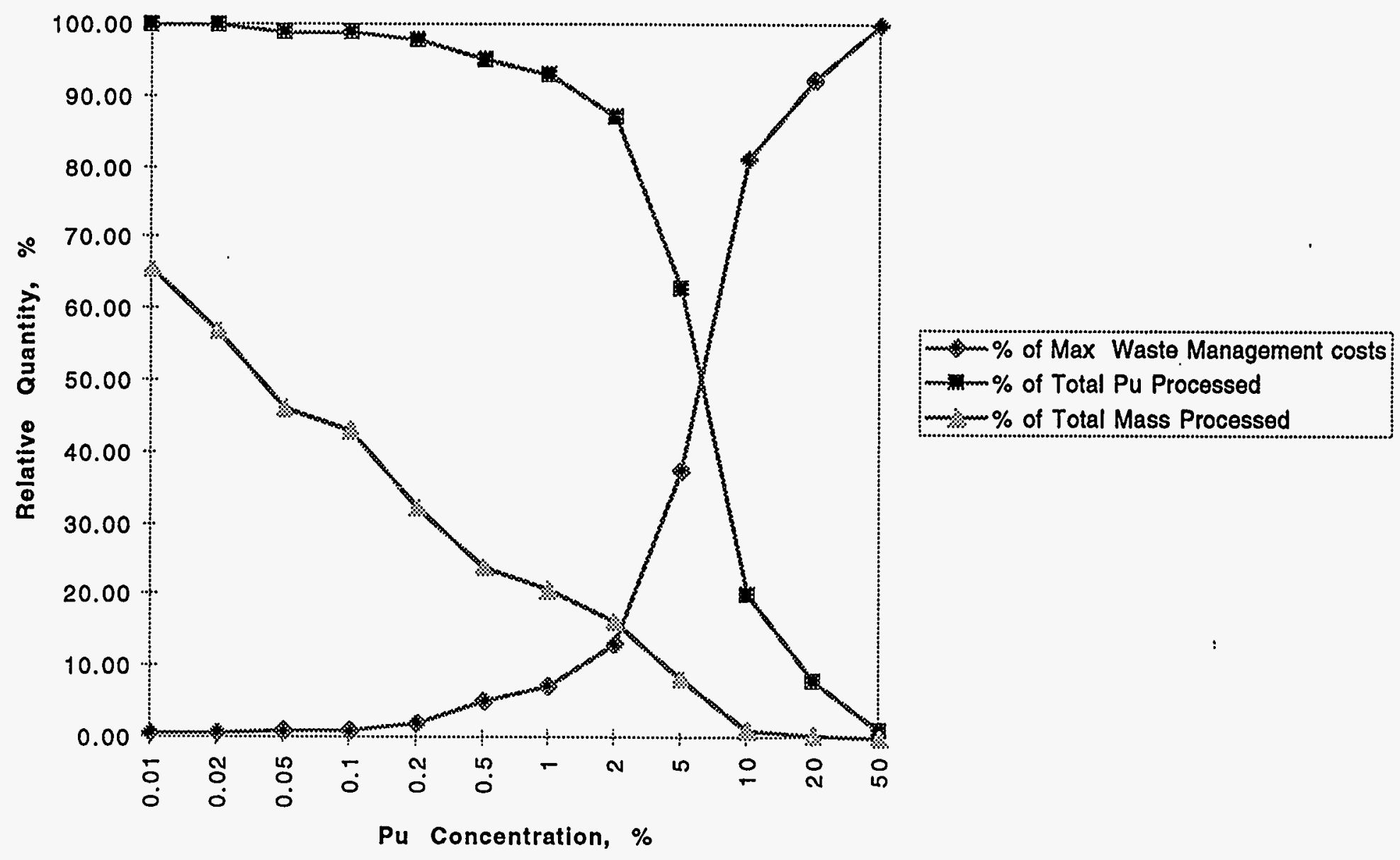


Figure 4: Information Available for Identification of Feed Materials for Materials Dispositon Program

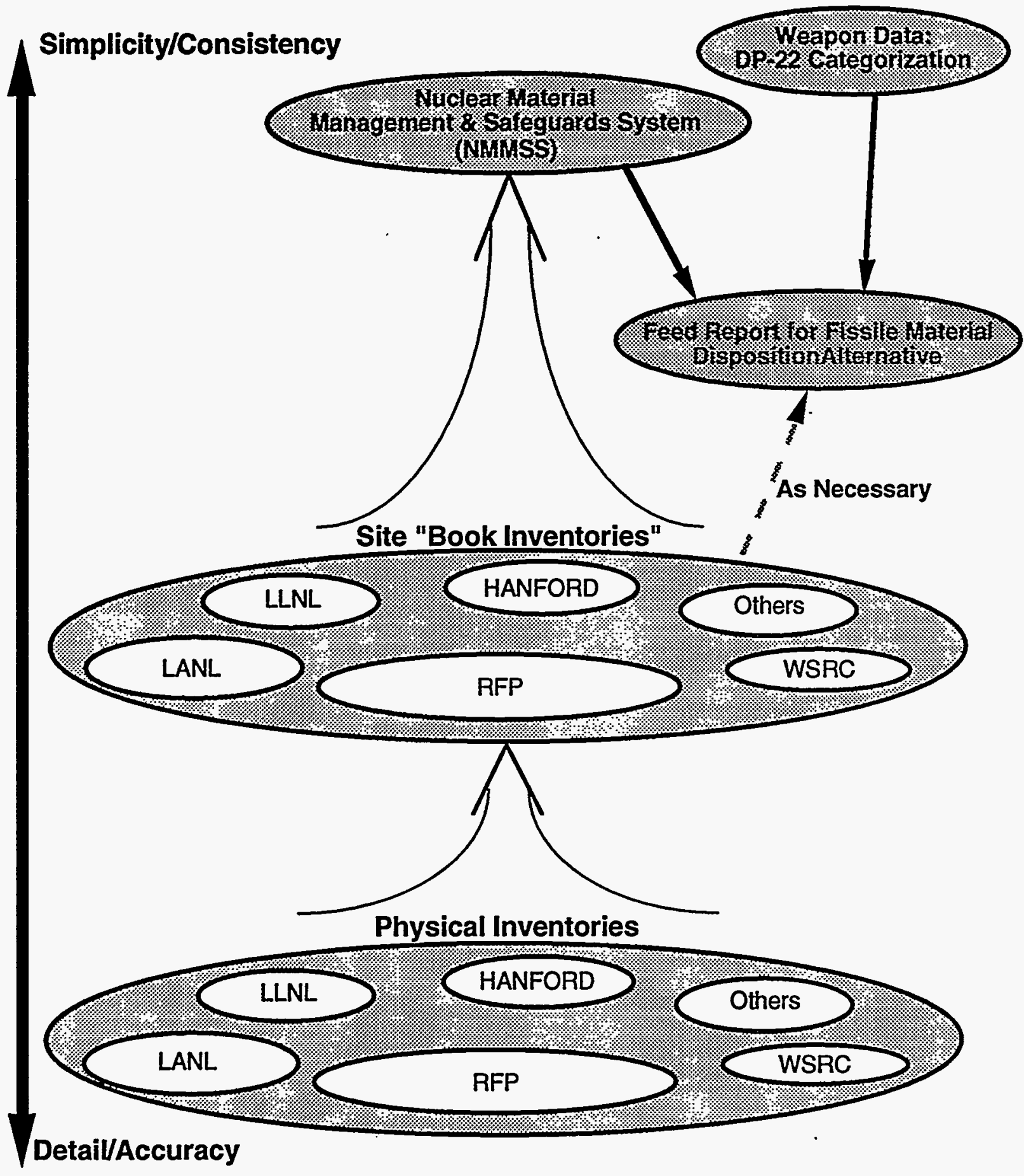




\section{Table C1. DOE Plutonium Excess to Defense Program Needs -- Main Categories}

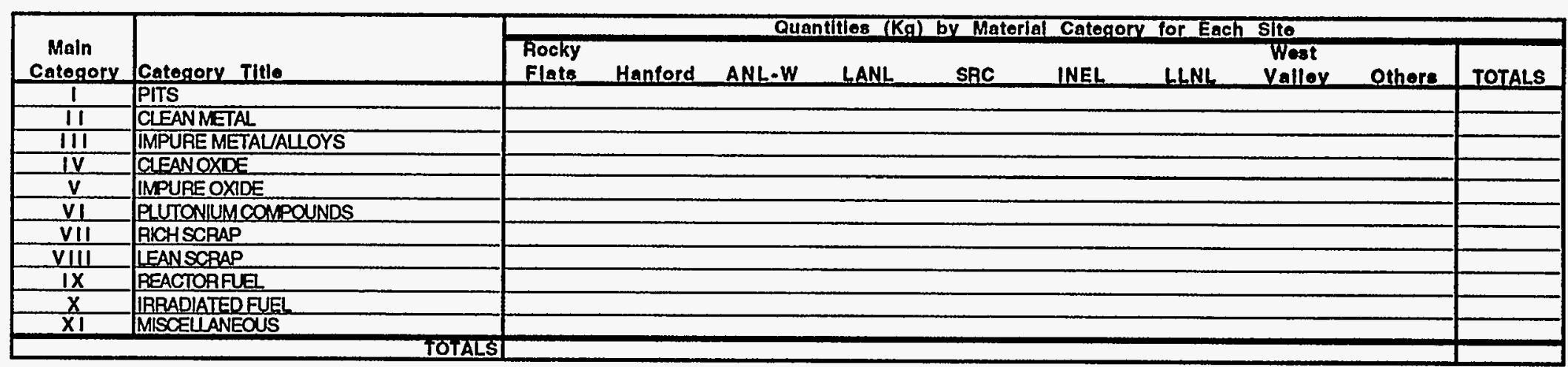

\begin{tabular}{|c|c|c|c|c|c|c|c|c|c|c|c|}
\hline \multirow[b]{2}{*}{$\begin{array}{c}\text { Main } \\
\text { Category }\end{array}$} & \multirow[b]{2}{*}{ Category Titlo } & \multicolumn{10}{|c|}{ Porcentage of Total Category, by Site } \\
\hline & & $\begin{array}{l}\text { Rocky } \\
\text { Flate }\end{array}$ & Hanford & ANL-W & LANL & SRC & INEL & LLNL & $\begin{array}{l}\text { Wost } \\
\text { Valley }\end{array}$ & Others & TOTALS \\
\hline 1 & PITS & & & & & & & & & & \\
\hline 11 & CEEANMETAL & & & & & & & & & & \\
\hline 111 & IMPURE METALALLOYS & & & & & & & & & & \\
\hline IV & CIEANOXDE & & & & & & & & & & \\
\hline $\mathrm{v}$ & IMPURE OXIDE & & & & & & & & & & \\
\hline VI & PLUTTONIUM COMPOUNDS & & & & & & & & & & \\
\hline VII & RICH SCPAP & & & & & & & & & & \\
\hline VIII & LEANSCPAP & & & & & & & & & & \\
\hline $\mathrm{IX}$ & REACTORFUE & & & & & & & & & & \\
\hline $\bar{x}$ & IRPADIATED FUEL & & & & & & & & & & \\
\hline$\overline{X I}$ & MISCELLANEOUS & & & & & & & & & & \\
\hline
\end{tabular}

\begin{tabular}{|c|c|c|c|c|c|c|c|c|c|c|}
\hline \multirow[b]{2}{*}{$\begin{array}{c}\text { Main } \\
\text { Catogory }\end{array}$} & \multirow[b]{2}{*}{ Category Titlo } & \multicolumn{9}{|c|}{ Percentage of Total slio, by Catogory } \\
\hline & & $\begin{array}{l}\text { Rocky } \\
\text { Flats }\end{array}$ & Hanford & $A N L \cdot W$ & LANL & SRC & INEL & LLNL & $\begin{array}{l}\text { Wost } \\
\text { valley }\end{array}$ & Others \\
\hline$I$ & PITS & & & & & & & & & \\
\hline 11 & CLFANMETAL & & & & & & & & & \\
\hline 111 & IMPUARE METAL/ALLOYS & & & & & & & & & \\
\hline IV & CLEANOXDE & & & & & & & & & \\
\hline $\mathbf{v}$ & IMPURE OXIDE & & & & & & & & & \\
\hline vi & PLUTONIUM COMPOUNDS & & & & & & & & & \\
\hline VII & RICHSCRAP & & & & & & & & & \\
\hline VIII & LEAN SCAAP & & & & & & & & & \\
\hline$\overline{I X}$ & REACTORFUE & & & & & & & & & \\
\hline $\bar{x}$ & IRRADIATED FUEL & & & & & & & & & \\
\hline$x \mid$ & MISCEUANEOUS & & & & & & & & & \\
\hline & & & & & & & & & & \\
\hline
\end{tabular}


Table C2. DOE Plutonium Excess to Defense Program Needs -- Material Grades

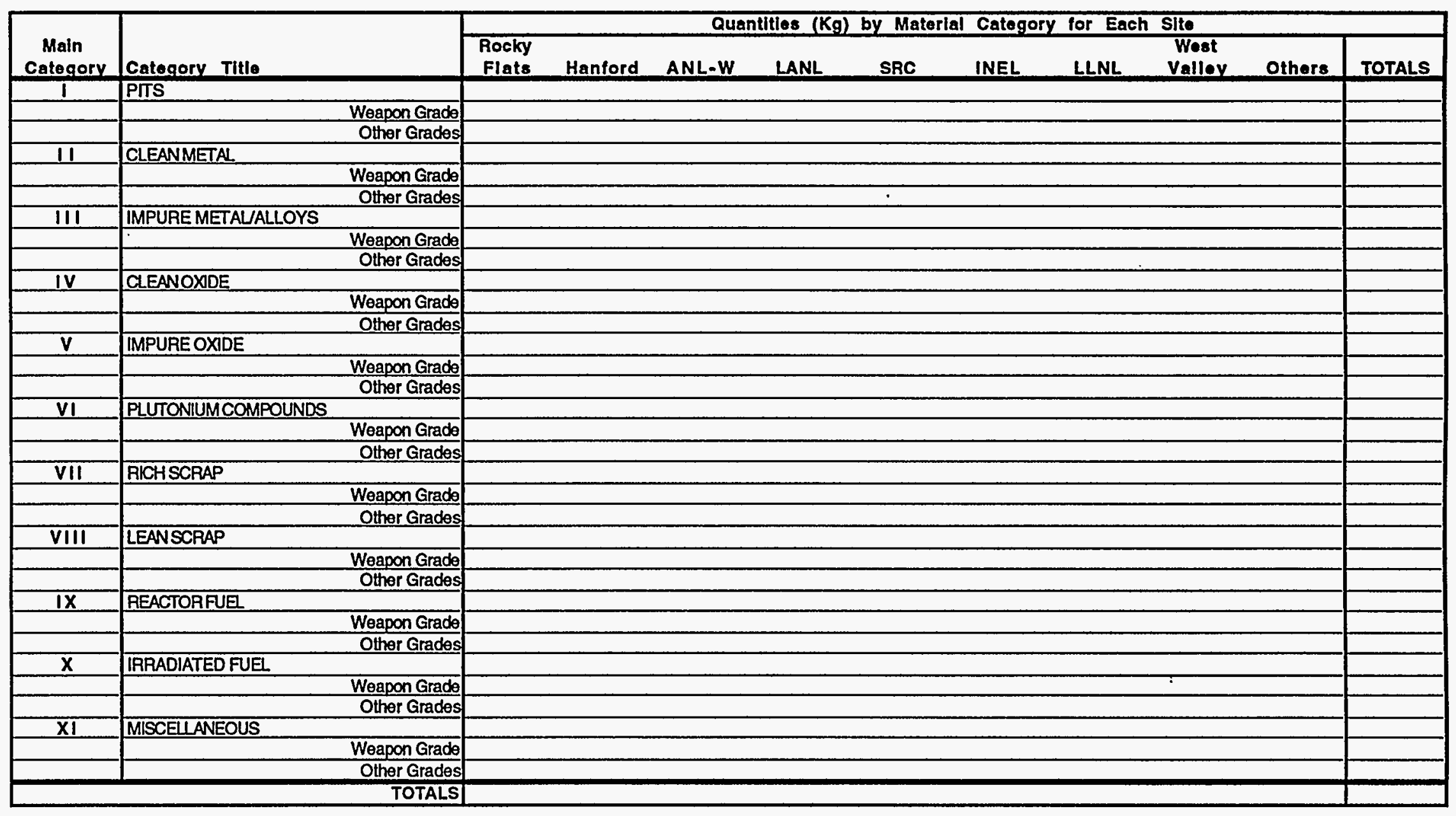


Table C3. DOE Plutonium Returns from Excess Weapons

Projected Pu Avallable

Planning Year from Excess Weapons
1995
2005 


\section{Table C4. DOE Plutonium Excess to Defense Program Needs -- Sub Categories}

\section{Clean Metal}

\begin{tabular}{|c|c|c|c|c|c|c|c|c|c|c|}
\hline $\begin{array}{l}\text { Cloan Motal } \\
\text { Sub Gategory }\end{array}$ & Malor ImpuritylForm & $\begin{array}{l}\text { Rocky } \\
\text { Flate }\end{array}$ & Henford & ANL-W & LANL & SRC & INEL & LLNL & Othere & TOTALS \\
\hline-1 & Buttons & & & & & & & & & \\
\hline 2 & Billets, Ingots, Castings, \& Rough Machining & & & & & & & & & \\
\hline 3 & Weapon Components & & & & & & & & & \\
\hline 4 & Recovered Metal, \& Misc. Small Parts & & & & & & & & & \\
\hline & TOI & & & & & & & & & \\
\hline
\end{tabular}

\section{Impure Metal/Alloys}

\begin{tabular}{|c|c|c|c|c|c|c|c|c|}
\hline $\begin{array}{c}\text { Impure } \\
\text { Motal/Alloy } \\
\text { Sub Category }\end{array}$ & Major Impurity/Form & $\begin{array}{c}\text { Rocky } \\
\text { Flate }\end{array}$ & Henford & ANL-W & LANL & SRC & INEL & LLNL \\
\hline 1 & Alloys Othere & TOTALS \\
\hline 2 & Impure Unalloyed Metal & & & & & \\
\hline TOTALS & & & & & \\
\hline
\end{tabular}

V. Impure Oxide

\begin{tabular}{|c|c|c|c|c|c|c|c|c|c|c|}
\hline $\begin{array}{l}\text { Impure Oxide } \\
\text { Sub category }\end{array}$ & Major Impurity/Form & $\begin{array}{l}\text { Roeky } \\
\text { Flate }\end{array}$ & Hanford & ANL-W & LANL & 8RC & INEL & LLNL & Othere & TOTALS \\
\hline 1 & Oxtoes & & & & & & & & & \\
\hline 2 & PU-DUANU Oxides & & & & & & & & & \\
\hline 3 & Pu-EU Oxides & & & & & & & & & \\
\hline 4 & Pu-Np Oxides & & & & & & & & & \\
\hline 5 & Pu-Th Oxides & & & & & & & & & \\
\hline 6 & Pu-Be Oxides & & & & & & & & & \\
\hline 7 & Pu-Zr Oxldes & & & & & & & & & \\
\hline & - & & & & & & & & & \\
\hline
\end{tabular}

VI. Compounds

\begin{tabular}{|c|c|c|c|c|c|c|c|c|c|c|}
\hline $\begin{array}{l}\text { Compounds } \\
\text { sub Category }\end{array}$ & Major Impurity/Form & $\begin{array}{l}\text { Rooky } \\
\text { Flats }\end{array}$ & Hanford & ANL.W & LANL & SRC & INEL & LLNL & Othere & TOTALS \\
\hline 1 & Carbldes & & & & & & & & & \\
\hline 2 & Hydrides & & & & & & & & & \\
\hline 3 & Nitfldes & & & & & & & & & \\
\hline 4 & Halldes & & & & & & & & & \\
\hline 5 & Encapsulated Compounds & & & & & & & & & \\
\hline 6 & Mlscellanoous Compounds & & & & & & & & & \\
\hline & & & & & & & & & & \\
\hline
\end{tabular}


Table C4. DOE Plutonium Excess to Defense Program Needs -- Sub Categories (cont'd)

VII. Rich Scrap

\begin{tabular}{|c|c|c|c|c|c|c|c|c|c|c|}
\hline $\begin{array}{l}\text { Rich Sorap Sub } \\
\text { Category }\end{array}$ & Major Impurity/Form & $\begin{array}{l}\text { Rooky } \\
\text { Flate }\end{array}$ & Hanford & ANL-W & LANL & SRC & INEL & LLNL & Othere & TOTALS \\
\hline 1 & Graphite & & & & & & & & & \\
\hline 2 & Ash/ Ash and Soot Hools & & & & & & & & & \\
\hline 3 & Heols & & & & & & & & & \\
\hline 4 & Plutonlum Fluorides & & & & & & & & & \\
\hline 5 & Sand, Slag, and Cruclble (SS\&C) & & & & & & & & & \\
\hline 6 & Insulation - Fillers & & & & & & & & & \\
\hline 7 & Ceramles (chlorld $\theta$-containlng) & & & & & & & & & \\
\hline 8 & Sludge & & & & & & & & & \\
\hline 9 & Chloride Salts/ Oxldes (chlorlde-containing) & & & & & & & & & \\
\hline 10 & Solutions & & & & & & & & & \\
\hline 11 & Non-Conforming Scrap & & & & & & & & & \\
\hline & TOTA & & & & & & & & & \\
\hline
\end{tabular}

\section{Reactor Fuel}

\begin{tabular}{|c|c|c|c|c|c|c|c|c|c|c|}
\hline $\begin{array}{l}\text { Reactor Fuol } \\
\text { sub Category }\end{array}$ & Malor Impurity/Form & $\begin{array}{l}\text { Rooky } \\
\text { Flats }\end{array}$ & Henford & ANL.W & LANL & SRC & INEL & LLNL & Othere & TOTALS \\
\hline 1 & Cladded & & & & & & & & & \\
\hline $\mathbf{a}$ & Metal & & & & & & & & & \\
\hline b & Oxida & & & & & & & & & \\
\hline c & Carbldes & & & & & & & & & \\
\hline d & Alloys & & & & & & & & & \\
\hline 2 & Non-Cladded & & & & & & & & & \\
\hline$a$ & Metal & & & & & & & & & \\
\hline b & Oxide & & & & & & & & & \\
\hline$c$ & Carbldes & & & & & & & & & \\
\hline d & Alloys & & & & & & & & & \\
\hline & & & & & & & & & & \\
\hline
\end{tabular}

\section{$\mathrm{XI}$. Miscellaneous}

\begin{tabular}{|c|c|c|c|c|c|c|c|c|c|c|}
\hline $\begin{array}{l}\text { Mlscollaneous } \\
\text { Sub Category }\end{array}$ & Major Impurity/Form & $\begin{array}{l}\text { Rooky } \\
\text { Flats }\end{array}$ & Hantord & ANL-W & LANL & SRC & INEL & LLNL & Othere & TOTALS \\
\hline 1 & Pu-Al Alloy & & & & & & & & & \\
\hline 2 & PU-U-Mo Alloy & & & & & & & & & \\
\hline 3 & Milxed Oxide & & & & & & & & & \\
\hline & & & & & & & & & & \\
\hline
\end{tabular}


Table C5: Expected and Bounding Values of Excess Pu Inventories by Material Category

\begin{tabular}{|c|c|c|c|}
\hline Material Category & Minimum Inventory & Planning Inventory & Bounding Inventory \\
\hline Pits & "X-94" & "X-2005" & $2^{* 11} \mathrm{X}-2005^{\prime \prime}$ \\
\hline Clean Metal & "Y" & $" \bar{"}$ & "Y" \\
\hline Impure / Alloyed Metal & "Z" & $\mathrm{ZZ}^{\mathrm{n}}$ & $\mathrm{ZZ}^{\mathrm{n}}$ \\
\hline Clean Oxide & $\mathrm{A}^{\mathrm{n}}$ & "A" & $\mathrm{A}^{\prime \prime}$ \\
\hline Impure Oxide & "B" & "B" & $\mathrm{B}^{\prime \prime}$ \\
\hline Compounds & $\mathrm{C}^{\prime \prime}$ & $\mathrm{C}^{11}$ & $\mathrm{C}^{\prime \prime}$ \\
\hline Rich Scrap * & $\overline{0}$ & $\mathrm{D}^{\prime \prime}$ & $\mathrm{D}^{\prime \prime}$ \\
\hline Lean Scrap * & $\overline{0}$ & $\overline{0}$ & $\overline{0}$ \\
\hline Reactor Fuel & "E" & "E" & "E" \\
\hline Irradiated Fuel * & $\overline{0}$ & $\overline{0}$ & $\mathrm{~F}^{\prime \prime}$ \\
\hline Miscellaneous & "G" & "G" & "G" \\
\hline Total & sum & sum & sum \\
\hline
\end{tabular}

* Note: Stabilized forms of Scrap or Irradiated fuel are assumed to be either impure oxide or impure metal 